\title{
FOSSIL WOODS FROM BOZOVICI (SW ROMANIA)
}

\author{
Stănilă Iamandei ${ }^{1 *}$, Eugenia Iamandei ${ }^{1}$ \& Tiberiu Stoia ${ }^{2}$
}

Received: 09 August 2019 / Accepted: 14 October 2019 / Published online: 25 October 2019

\begin{abstract}
A palaeoxylotomical study was done on several samples from a private collection of petrified wood found in Bozovici area, which were taxonomically identified. Bozovici area is a small Badenian depression filled by coarse continental deposits, with some interbedded coal and volcanic tuffs. The frequent lateral facies variations and the few fossils of fresh water fauna make difficult a stratigraphic correlation of these deposits. Those samples of fossil wood were identified as remains of Glyptostroboxylon rudolphii Dolezych et Van der Burgh and Spiroplatanoxylon densiradiatum (Petrescu) Süss and an extended discussion concerning the systematics of these taxa was made. Advanced studies on more numerous samples coming from Bozovici area could contribute to a better palaeoenvironmental and palaeoclimatic reconstruction of that area, during Badenian time.
\end{abstract}

Keywords: Bozovici depression, Badenian coal, petrified wood, Glyptostroboxylon, Spiroplatanoxylon.

\section{INTRODUCTION}

One of the authors of the present paper (T. Stoia), has organized some outdoor exhibitions in Bocșa and Gărâna localities, (Banat, Romania), with stumps and logs of petrified woods collected from different places in Romania. Some samples collected by him from Bozovici area (i.e. Almăj Depression) were brought to the National Geological Museum in Bucharest, and represent the subject of the present study. In Bozovici Depression occurs a coal-bearing geological formation of Badenian age, preserving numerous remains of coalified wood and sometimes petrified (Iliescu et al., 1967). Since there are no paleoxylotomical studies ever done on this fossil wood, we started a study of these samples in order to get new informations about the composition of the ancient forest involved in the local coal -genesis. In this context, the purpose of the paper is firstly, to identify the petrified wood remains from Bozovici Depression, and also to discuss palaeoenvironmental and palaeoclimatic reconstruction of that region during Badenian time.

\section{GEOLOGICAL SETTING}

The Bozovici Depression (also known as Almăj Depression, Fig. 1) is located in South-Western part of Romania, Caraș-Severin county (Fig. 1), in a small Badenian graben, probably initiated during the Early Miocene and is linked, to east, with Caransebeș-Mehadia depression, another tectonic Miocene corridor filled with similar Badenian continental coarse deposits: conglomerates, calcareous sandstones, sands, pebbles, marls, banded clay, interbedded coals and volcanic tuffs (Oprea, 2014).

The frequent lateral facies variations and the fossils scarcity (only a few fossils of fresh water fauna was reported) bring difficulties in establishing a precise stratigraphic sequence of those deposits. Even if the region presented interest for coal and also for gold, many years ago (see Pomârleanu \& Mârza, 2002), few geological investigations were done in the area.
Fifty years ago, geological prospections in this area, have described a coaly level between Bozovici and Lăpuşnicul Mare, on Lighidia and Agrişului valleys. This coaly subhorizon consists of clay with pyrite concretions overlaying marls and green-greyish or red clay and being overlain by grey-yellowish marls and limestones with Corbula sp. and Terebralia bidentata Defrance, and a coaly bed presenting numerous silicified tree trunks at its upper part (Iliescu et al., 1967).

The upper sequence, "the Valea Slătinicului Member" (see Fig. 2), has a fluvial-lacustrine aspect, it is well but irregularly developed, having 50-150 m in thickness, and is attributed to the Badenian (i.e. upper part of Moravian +/- basal Wielician), overlaying an unconformity (erosional event) with a basal tuff (=Slătinic Tuff) followed by silty sandstones and clay, and coarser intercalations up to the basal tuffaceous level of Dalboșeț Formation (Codrea, 2002; see Fig. 2). At the upper part of Valea Slătinicului Member some coaly seams of variable thickness (up to $11 \mathrm{~m}$ ) appear, containing also some petrified tree trunks (marked also by Barbu \& Brănoiu, 2018, in Fig.2).

In the same deposits some micro-mammals were described from drilling material (Codrea, 2002). The age of the geological formation supposed to be Early Miocene by Grigorescu (1985), was specified by Petrescu \& Nicorici (1989), based on the palynologic study of the drilling Lighidia 6442B. Stratigraphically analyzed, the sporopolinic association from the lower part of the sedimentary succession indicates the Eggenburgian, and suggests also the paleoclimate parameters (mean annual temperatures, $\mathrm{MAT}=16-17^{\circ} \mathrm{C}$ and mean annual precipitations, MAP $=1200-1800 \mathrm{~mm}$ ).

In the upper part of the succession, the thermophilic species become fewer, while the temperate ones appear and even indications of storeyed vegetation are documented, probably as a result of some landscape modifications by tectonic uplift. The palynologic assemblage was interpreted as indicating the Ottnangian stage (Petrescu, 2003, p. 161-163). The list of flora, suggested by the 


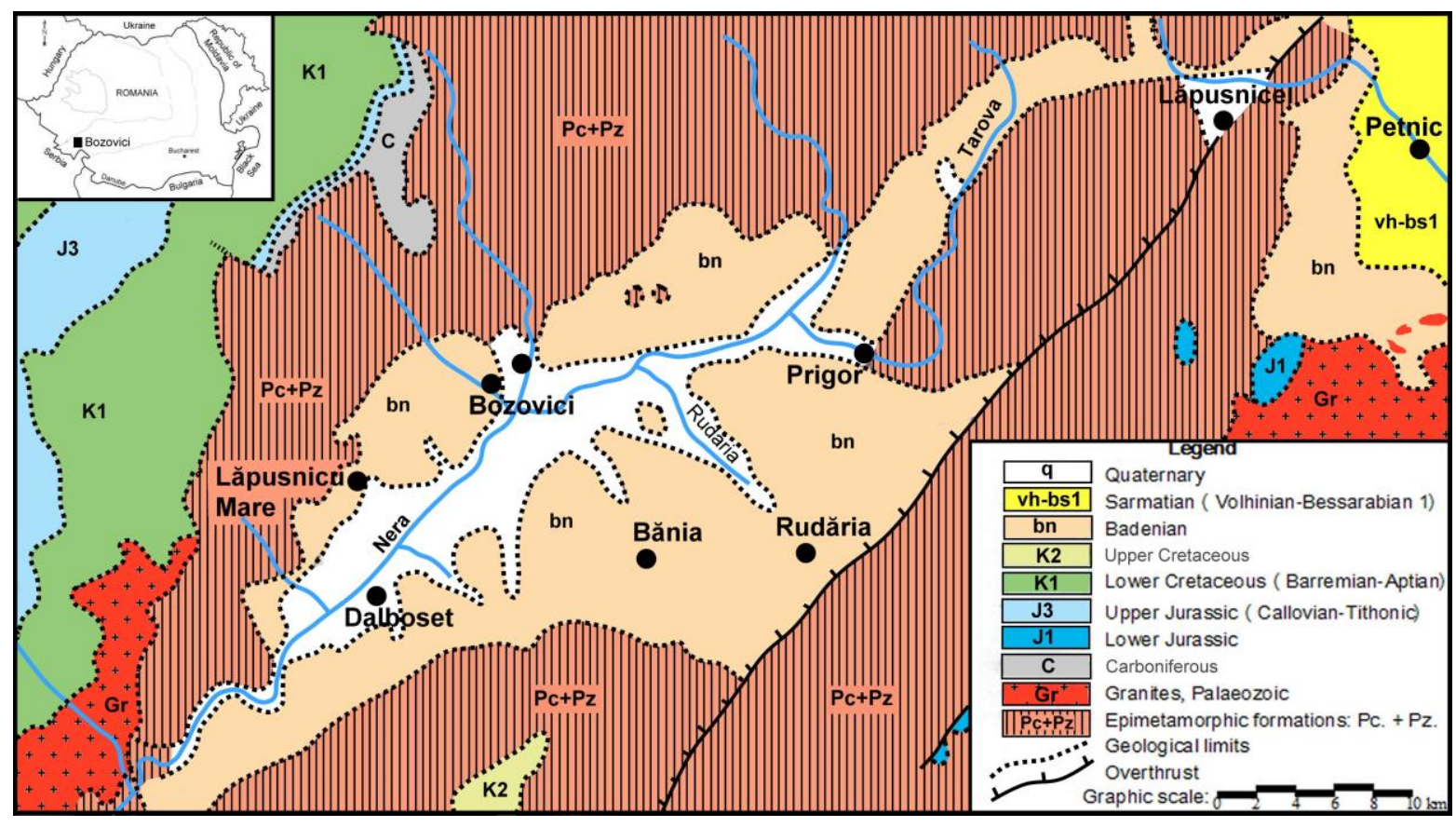

Fig. 1 Geological map of Bozovici Depression (redrawn after Codarcea et al., 1968. Geological maps 1:200,000, Sheet 31 Reşiţa and Sheet 32 - Baia de Aramă). Graphic scale.

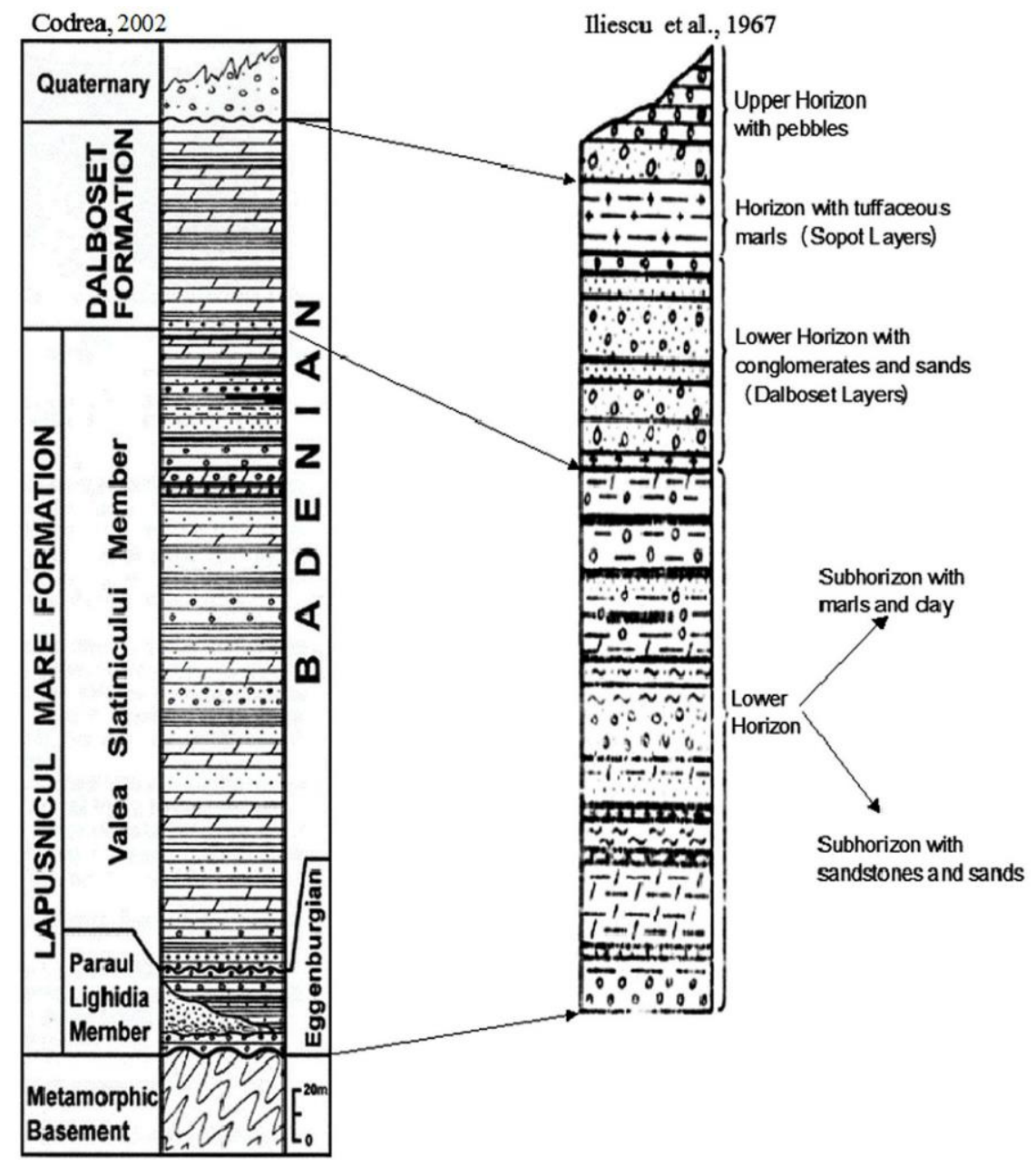

Fig. 2 Correlated stratigraphic columns in Bozovici Basin (from Iliescu et al. 1967; Codrea, 2002). 
sporopolinic study of Petrescu (2003), beside numerous Pteridophytes, possible Cycads and herbaceous Angiosperms - with graminaceous, sparganiaceous, liliaceous taxa, numerous arboreal plants appear. Firstly, some conifers as Abies, Picea, Pinus, Larix(?), Sciadopitys, and Sequoia, some other Cupressaceae(?) and, probably some Podocarpacee(?) also appear. Also numerous Angiosperms were indicated - as Magnolia, Myrica, Juglans, Celtis, Engelhardia, Carya, Platycarya, Alnus, Betula, Carpinus, Ulmus, Tilia, Nyssa, Fagus, Quercus and other diverse members of Symplocaceae, Onagraceae, Caprifoliaceae, Elaeagnaceae, Proteaceae, Myrtaceae, Malpighiaceae, Ericaceae, Cyrillaceae, Sapotaceae, Compositae, and even Palms (see Petrescu, 2003, p. 161163).

\section{MATERIAL AND METHODS}

Five samples of petrified wood were collected from Bozovici depression from mid-Badenian deposits from the upper part of Valea Slătinicului Member, Lăpuşnicul Mare Formation (see Fig. 2). Two of them can be seen in Fig. 3. The studied material is deposited in the Collection of the National Geological Museum.

From each sample three thin sections of petrographic type after the standard directions, (transversal, tangential and radial) were executed. These sections have been studied under the optic microscope and all anatomical details were described for each specimen. After this, by comparison with previously described similar aspects of extant or fossil wood structures the identification of the unknown tree was performed.

\section{PALAEOXYLOTOMY}

Family Cupressaceae Gray, 1822 nom. cons. (sensu Farjon 2005b)

Subfamily Taxodioideae Endl. ex K.Koch, 1842 Genus Glyptostroboxylon (Conwentz) emend. Dolezych et Van der Burgh, 2004

Glyptostroboxylon rudolphii Dolezych et Van der Burgh, 2004

Fig. 4, a-i. Fig. 5, a-i.

\section{Macroscopic description}

The studied material is represented by four samples of petrified wood: three centimetric-sized samples and one of them as a big slice cut from a silicified trunk (Fig. 3). All of them indicate a partially coalified wood and then silicified, showing dark color, fibrous texture and quasiregular growth rings visible with the naked eye, suggesting a conifer structure. Standard oriented thin sections were made and microscopic study was done on four samples. The studied material is deposited in the Collection of the National Geological Museum (NGM Col. Bucharest) under the indicative numbers: 27,618; 27,619; 27,620 and 27,621 (in Fig. 3).

\section{Microscopic description}

The growth rings in cross section seen are distinct, broad, but rather unequal in width.
The transition from earlywood to latewood is gradual. The boundaries of the annual rings are distinct, marked by 3-15 tangential rows of thick-walled to very thickwalled and smaller cells of the latewood. There are no normal axial resin ducts and the ring boundaries are often wavy, probably due to the buttressed form of trunk.

The tracheids are polygonal in cross section, with slightly rounded corners in the earlywood and with radial/tangential diameters of 25-75/30-55 $\mu \mathrm{m}$, smaller in the latewood, of 25-30/17-25 $\mu \mathrm{m}$. The tracheidal wall has 5$10 \mu \mathrm{m}$ in the early wood, growing to $12-17 \mu \mathrm{m}$ the double wall, in the latewood. There are 2-11 radial regular rows between two successive rays. On the tangential walls there are few, uniseriate, spaced or slightly irregular abietineous small bordered pits, of 6-8-10 $\mu \mathrm{m}$ in diameter, with small circular apertures, or vertical elliptic. The radial pits is opposite, typical abietineous, of 12-16 $\mu \mathrm{m}$ in diameter and smaller in the latewood, in 1-4 vertical rows, spaced or contiguous, sometimes presenting small irregularities in their arrangement. Crassulae are occasionally present. No helical thickenings were seen on the tracheids.

The axial parenchyma is few, dispersed, less visible in cross-section, since not always has dark content and it appear similar to tracheids. In vertical view it appears as rectangular thin-walled cells (1-3 $\mu \mathrm{m}$ the simple wall), with thin terminal (horizontal) walls smooth, slightly rugose or nodular, with 1-3 nodules. Inside, it has large dark resinous balls, or plugs with rounded endings, sometimes with convex empty spaces, or as small remains.

The rays are usually uniseriate, sometimes with local short biseriations or even biseriate, having 2-15-36 or more cells in height. Sometimes, they seem to be heterogeneous in tangential view, with often unequally sized cells, either higher, or wider (as wide as two cells when occur in biseriate rays), and have lateral intercellular spaces. Ray density is 4-8 rays per horizontal tangential $\mathrm{mm}$ and up to 40 rays per square $\mathrm{mm}$. In radial view, the procumbent ray cells have thin and smooth horizontal walls of 2-3 $\mu \mathrm{m}$, height of $12-17 \mu \mathrm{m}$ or more, the marginals are slightly taller (of 20-35 $\mu \mathrm{m}$ ) and have wavy outer wall. Ray-tracheids are not present. The tangential walls are slightly nodular, and indentures were not observed. The earlywood cross-fields have 3-4 glyptostroboid, sometimes taxodioid pits, but with much reduced borders, like cupressoid type, of 8-10 $\mu \mathrm{m}$, arranged in horizontal rows, or in slightly diagonal pairs, or single in the late-wood cross-fields. In the marginal cross-fields, up to 8 pits in 1-2 horizontal rows were observed. The pit apertures are nearly round or elliptical oblique.

\section{Affinities and discussions}

The synthetic description of these specimens provided xylotomical details typical for the cupressaceous woods, especially of „taxodiaceous“ type, by the absence of the resin ducts, the shape of the tracheids, their size and wall thickness, the ray aspect in longitudinal sections, especially the presence of radial opposite pitting on 1-4 vertical rows, with crassulae on tracheids, and the cross-fields with typical glyptostroboid pitting, tending sometimes to taxodioid or even cupressoid aspect. These observed details have been compared with extant and fossil published 


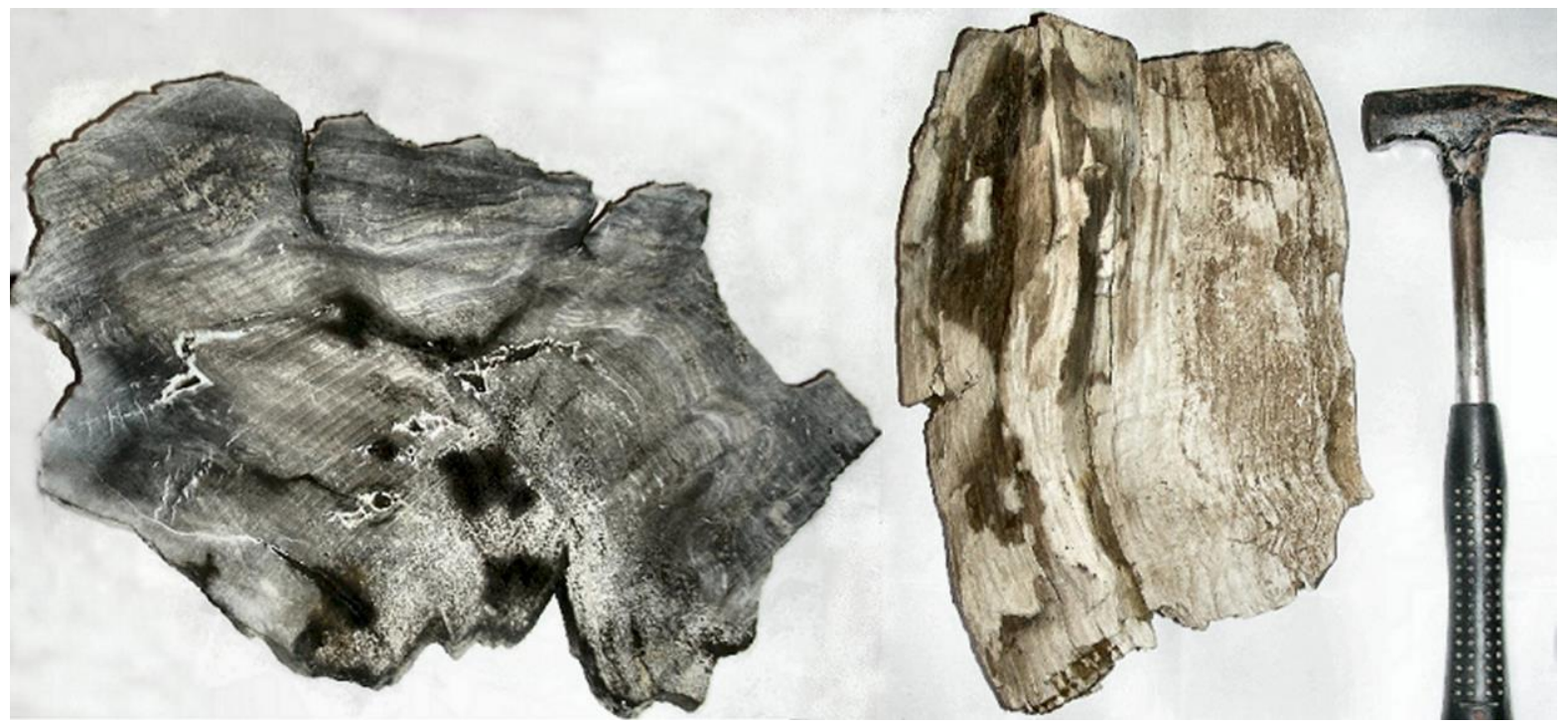

Fig. 3 Two of the studied samples (nos. 27621, 27622).

structures of Cupressaceae of taxodiaceous type (Greguss, 1955; Visscher \& Jagels, 2003; Dolezych \& Van der Burgh, 2004; InsideWood, 2004 - onwards).

The family Cupressaceae s.l., beside the classical cupressaceous members (Callitroideae and Cupressoideae), comprises now all the members of the former ,taxodiaceous" genera, with both extant and fossil forms (Gadek et al., 2000; Farjon, 2005, 2017), included in the next subfamilies:

- Taxodioideae Endl. ex K.Koch, with Taxodium Rich., Glyptostrobus Endl., and Cryptomeria D.Don;

- Sequoioideae (Luerss.) Quinn, with Sequoia Endl., Sequoiadendron J.Buchholz and Metasequoia $\mathrm{Hu} \&$ W.C.Cheng;

- Athrotaxidoideae Quinn, with Athrotaxis D.Don;

- Cunninghamhioideae (Sieb. and Zucc.) Quinn, with Cunninghamia R.Br.;

- Taiwanioideae L.C.Li, with Taiwania Hayata.

Comparing the anatomical structure of the studied material with fossil "taxodiaceous" genera (Greguss, 1967) we found some similarities with Sequoioxylon Torrey, 1923 with Taxodioxylon (Hartig) Gothan, 1905 but especially with Glyptostroboxylon Conwentz, 1884. The distinction between those three genera is problematic enough, since some paleoxylologists contest the validity of the genus Sequoioxylon Torrey, considering that the diagnosis of Taxodioxylon genus is sufficiently comprehensive and the establishment of new domains of competence can complicate the fossil wood identification (Privé-Gill, 1977).

A more recent revision of the fossil cupressaceous morphogenera (Dolezych \& Van der Burgh, 2004) resulted in new revised diagnoses of them. Since it appears to be more similar to our material, we reproduce here only the diagnosis of the genus Glyptostroboxylon Conwentz, 1884, as is emended by Dolezych \& Van der Burgh (2004):

Coniferous wood with distinct growth rings. Tracheids in the earlywood wider than in the latewood. On the radial walls of tracheids, pits in 1-3(4) vertical rows. Wood parenchyma with thin and smooth to moderately thick and pitted terminal (horizontal) walls. Rays are homoge- neous, mostly uniseriate. Cross-field pits in the earl ywood are predominantly glyptostroboid, but also some cupressoid and taxodioid pits may be present.

In our studied specimens, the pattern of tracheids within the growth-rings, their radial abietineous pitting, spaced arranged in 3-4 vertical rows on wider earlywood tracheids, in 1-2 rows on the narrower latewood tracheids, the presence of axial parenchyma with smooth to quite nodular horizontal walls, the homogeneous, mostly uniseriate rays, sometimes with biseriate storeys or even as biseriate rays, the ray-cells with tangential walls slightly rugose, sometimes nodular, and the cross-fields with 1-4 glyptostroboid (and taxodioid) pits - more numerous, on two horizontal rows, in the marginals - represent a combination of features very similar to those described by authors for Glyptostroboxylon rudolphii Dolezych et Van der Burgh, 2004 and, obviously, with the species diagnosis.As it was shown by Dolezych \& Van der Burgh (2004) in their revision, Glyptostroboxylon tenerum (Kraus) Conwentz, 1884 was the initial basionym for the genus (its first name was Glyptostrobus tener Kraus, 1864). It was taken later again in discussion by Seward (1919, p. 198) and Jurasky (1933), but only Kraüsel (1949) was the one who established the correct name, in respect of ICBN Rules, however noting the wide variability of the glyptostroboid pits, up to the cupressoid, in the cross fields.

Now, Glyptostroboxylon tenerum is interpreted as fossil wood of Cunninghamia, because Gothan (1905) and later, Rudolph (1935), Watari (1948), Süss \& Velitzelos (1997) and Fairon-Demaret et al. (2003) have also observed affinities between the wood of Glyptostroboxylon tenerum and the one of the extant Cunninghamia, and Dolezych \& Van der Burgh (2004), after a new investigation on the original material from Wetterau, the type-locality, have observed that the affinity of this wood is not to Glyptostrobus, but clearly to Cunninghamia. Thus, they have described a new species of Glyptostroboxylon (G. rudolphii), emending also the genus' diagnosis and taking it as basyonim. The species name come from the name of a scientist who, they say, firstly discussed the affinity of the fossil to the recent wood of Cunninghamia vs. 
Gy (4) (5) son hor H

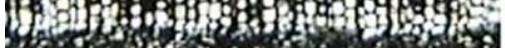
. 50 , For

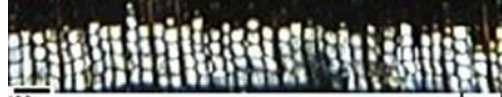
a
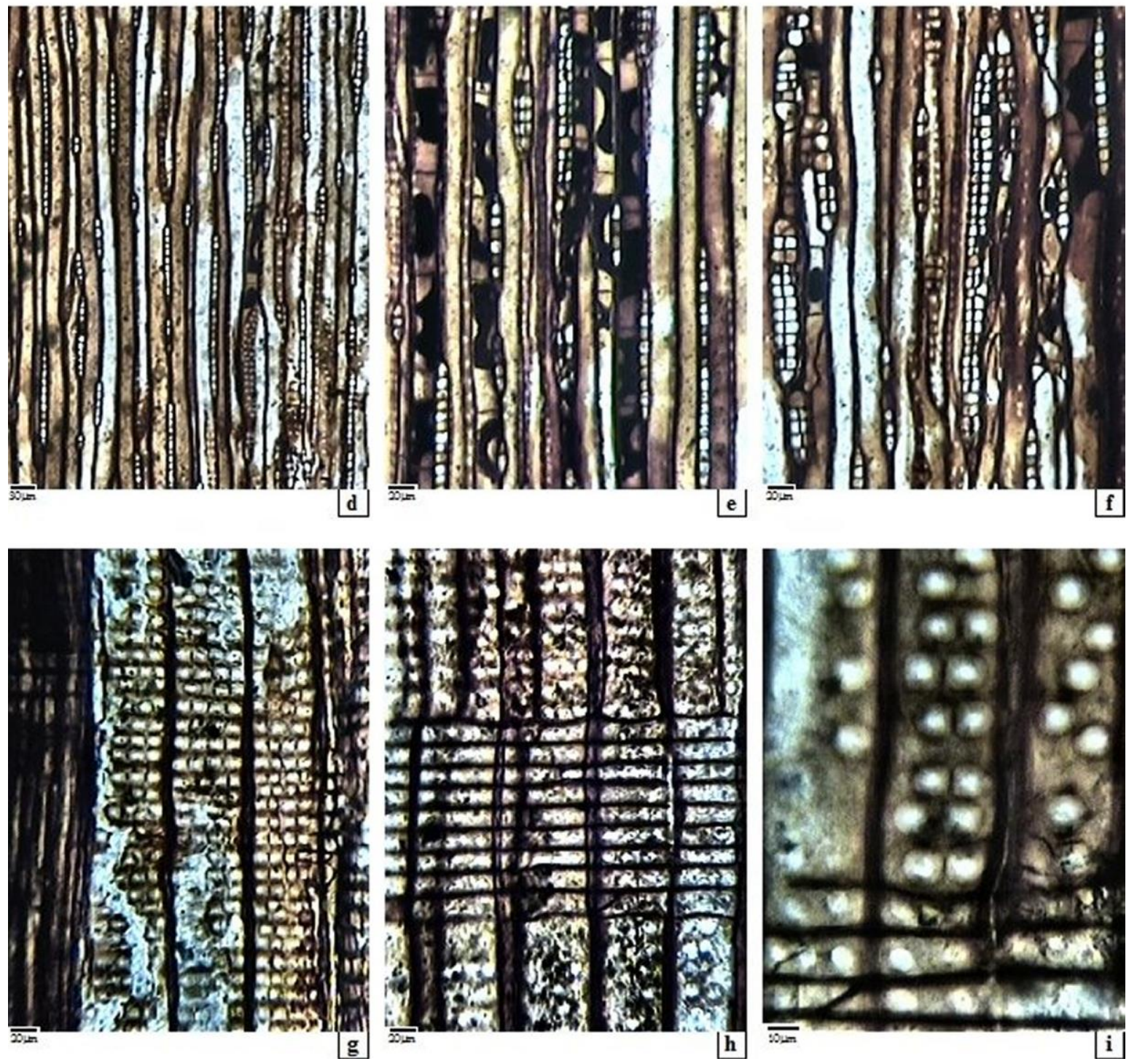

Fig. 4 a-i. (graphic scale, $\mu \mathrm{m}$ ). Glyptostroboxylon rudolphii Dolezych et Van der Burgh 2004, Bozovici, Romania. a-c. Cross section - distinct growth rings, earlywood and latewood tracheids. d-f. Tangential section - uniseriate and biseriate rays, parenchyma with resin plugs and smooth or nodular terminal (horizontal) walls. g-i. (radial section) - up to 4seriate radial pitting on tracheids, 1-4 pits cross fields (i), or 2-8 in marginal cross fields (i). 

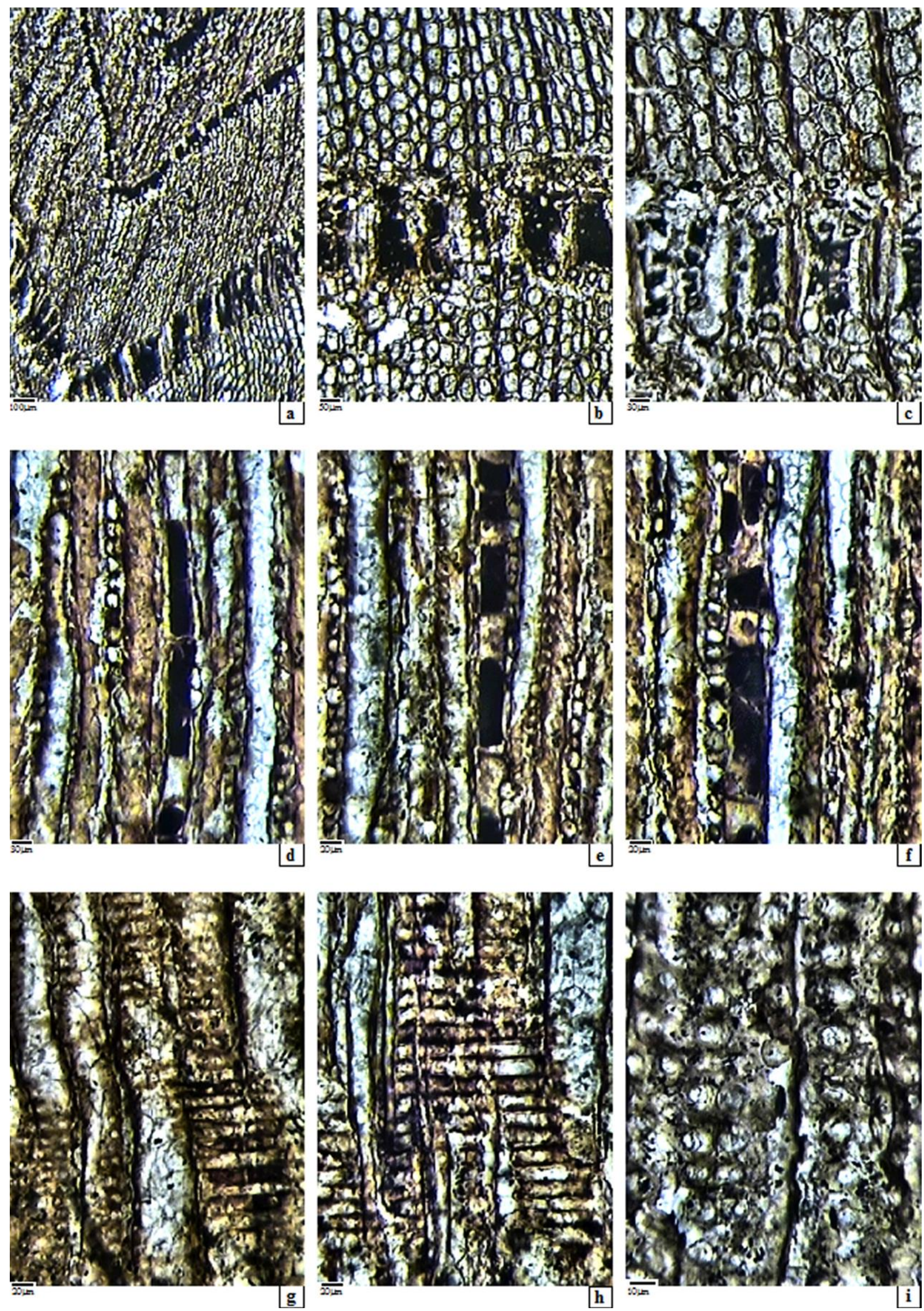

Fig. 5 a-i. (graphic scale, $\mu \mathrm{m}$ ). Glyptostroboxylon rudolphii Dolezych et Van der Burgh 2004, Bozovici, Romania.

a-c. (cross section) - earlywood and thick-walled latewood tracheids, wavy growth rings. d-f. (tangential section) - uni- and biseriate rays, parenchyma with resin plugs and nodular terminal (horizontal) walls. g-i. (radial section) - radial 1-3-4 seriate pitting on tracheids, 1-3-4 pits cross fields, more in marginal cross fields. 
Glyptostrobus (Rudolph, 1935), observing that the pits in cross-fields of the fossil wood are glyptostroboid and taxodioid, in a random distribution.

The newly described species, Glyptostroboxylon rudolphii Dolezych et Van der Burgh, 2004 represents, most probably, the fossil wood of Glyptostrobus europaeus (Brongniart) Unger, described on the basis of adpressions of shoots, leaves and cones, and frequently found in the European Cenozoic formations (see Greguss, 1967; Hofman, 1952; Ramanujam, 1960; Zalewska, 1953).

An interesting discussion is made by Teodoridis \& Sakala (2008), who observed that there is a disproportion between abundant leaves and cones/seeds of Glyptostrobus in the Most Basin (Czech Republic) and only one specimen of fossil wood found preserved as xylite rather difficult to identify, attributable to this genus, traditionally considered as the main coal-generating element: "association of Glyptostrobus" sensu Kvaček \& Buzek (1982) (in Kvaček, 1999; Teodoridis \& Sakala, 2008, p. 307).

As information, the monotypic extant genus Glyptostrobus pensilis (Staunton) K. Koch, named Shui Song (water pine), or Chinese deciduous cypress, or Canton water pine, is a not very tall tree, of relatively warm and wet climate, which can resist in colder climate too, having deciduous shoots. Even if it lived in Europe during the Cenozoic as an important coal-generator tree, maybe as an eco-form adapted to a wet environment, like peat-bog, the extant biogeographic areal of Glyptostrobus is very restricted, in some low, damp and riparian areas, in South-east China (Guangzhou) and Vietnam (Greguss, 1955; Earle, 1998). It appears also in Japan and in the West part of North America, as Jim Basinger, Professor of Saskatchewan University - Canada observed, and sent us this information (written comm., 1998): "I have seen it growing in the United States, Japan, and China. Living trees are generally found in relatively warm climates. In southern China (Guangzhou) the trees are semideciduous. Some foliage is retained all year. In cooler climates, it will be entirely deciduous. This is the case in the mid-western United States and in Japan. In the fossil record, for instance in the arctic fossil floras we have worked with, it appears that the trees were entirely deciduous. I believe that the conflicting reports on the evergreen or deciduous character of Glyptostrobus were the result of observation of trees under different climatic regimes".

After the revision and emendation of Glyptostroboxylon genus, new specimens were described and other revised as Glyptostroboxylon rudolphii Dolezych et Van der Burgh, 2004:

- Teodoridis \& Sakala (2008) studying a fragment of sideritized wood from Bílina Mine, from the Most Basin, described G. rudolphii, as having crassulae, large intercellular spaces between ray-cells and cross-field pits exclusively glyptostroboid.

- Vassio et al. (2008), described G. rudolphii from Middle Pliocene, studying in situ stumps from Stura di Lanzo right riverbank, NW Italy, based on their typical features, especially the presence of exclusively glyptostroboid cross-field pits.

- Dolezych, in Erdei et al. (2009) studying xylotomically stumps from the Miocene Fossil Forest of Bükkábrány
(Hungary), described wood structures comparable to Glyptostroboxylon Conventz emend. Dolezych and Van der Burgh, having similar cross-field pits. Such an idea is confirmed also by the presence of the organic-rich sediments underlying and embedding the stumps, which provided a high abundance of Glyptostrobus Endlicher wood remains, foliage, cones and seeds.

- Gryc \& Sakala, (2010), took again in study some woods from the Miocene opencast lignite mine of Bükkábrány (Hungary), exposed in the Visitor Centre of the Ipolytarnóc Fossils Nature Reserve, and described Glyptostroboxylon rudolphii, having cross-field pits mainly glyptostroboid.

- Havelcová et al. (2013) described G. rudolphii from the Stump Horizon in the Bílina open cast mine (Czech Republic), having typical details.

- Koutecky \& Sakala, (2015) described G. rudolphii also from Doupovske hory, Czech Republic, having glyptostroboid and taxodioid pits (1-2, occasionally up to 4) in cross-field, and rays up to 12 cells high.

Some forms of Glyptostroboxylon previously described, could be reassigned to the real equivalent of Glyptostrobus, i.e. Glyptostroboxylon rudolphii Dolezych et Van der Burgh (2004), since they are characterized mainly by glyptostroboid cross-field pits.

- Thus, the species described by Kostyniuk (1938), as having oval or round and glyptostroboid pits in crossfields, clearly agree with G. rudolphii, to which it could be reassigned.

- Iamandei et al. (2001), described a specimen from the Early Sarmatian from Leucuşeşti - Fălticeni, Northeastern Romania as $G$. tenerum wich could be reassigned too, as G. rudolphii, having also glyptostroboid crossfields.

- Nagy et al. (2002) described G. tenerum from the late Badenian deposits of Prăvăleni (South Apuseni Mountains), which can be reassigned to G. rudolphii.

- Recently, Akkemik et al. (2017) published the first Glyptostroboxylon from central Turkey, and then Akkemik et al. (2019) identified G. rudolphii from another site of central Turkey based on the nearest features such as 2-5 pits per cross-field, predominantly glyptostroboid, but also taxodioid and apparently higher ray height.

Therefore, taking into account the entire discussion and the affinities of our studied specimens, found at Bozovici area, we think they could be attributed to the species Glyptostroboxylon rudolphii Dolezych et Van der Burgh, 2004, probably representing fragments of trunk or thick branches, as the size of the tracheids and of the ray cells show, which is also in accord with the observations on the annual rings.

Family Platanaceae Lestiboudois, 1826 (ex Dumortier, 1829), nom.cons.

(APG III 2009, APG IV 2016)

Genus Spiroplatanoxylon Süss, 2007

Spiroplatanoxylon densiradiatum (Petrescu) Süss, 2007

Fig. 6, a-i. 

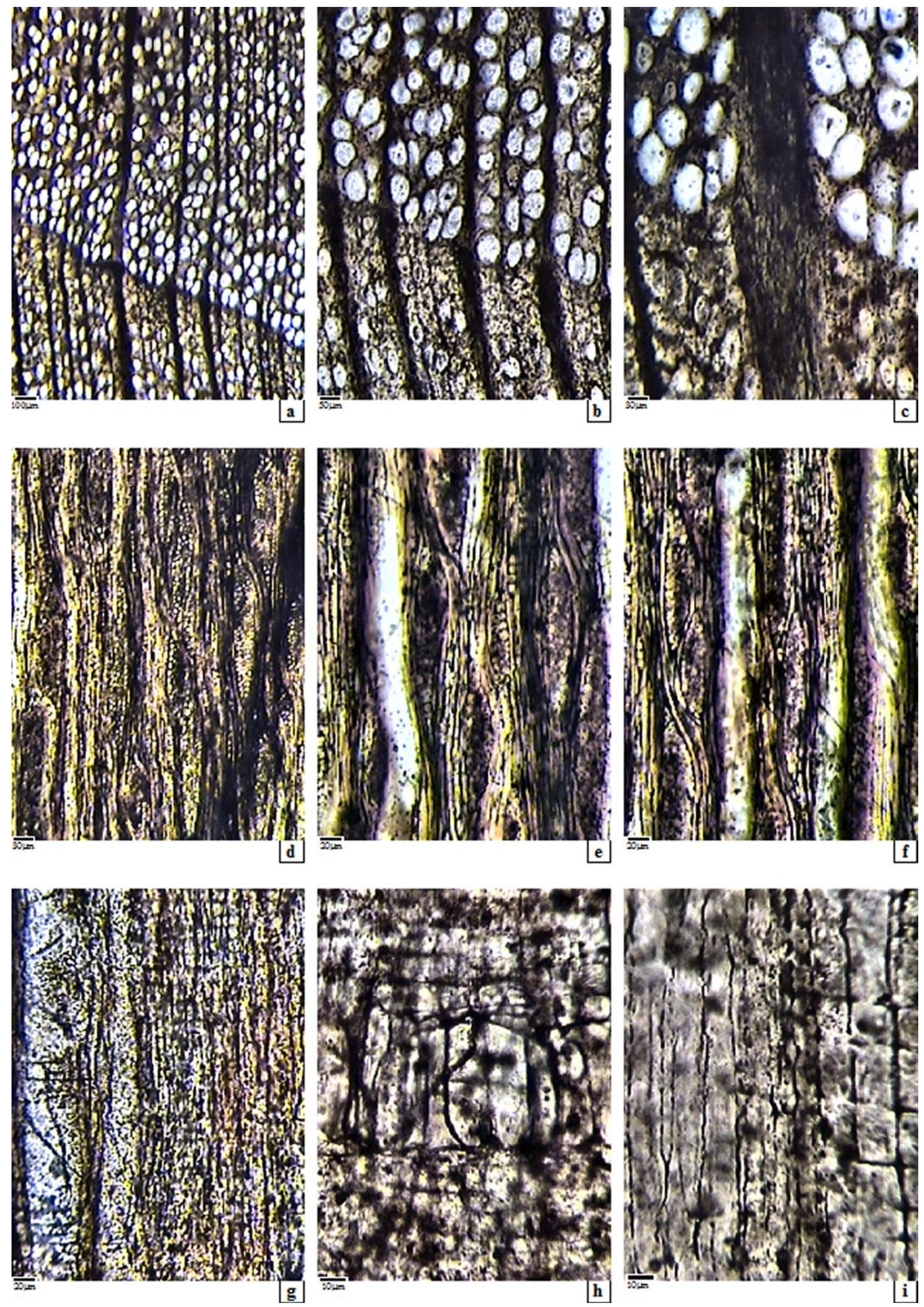

Fig. 6 a-i. (graphic scale, $\mu \mathrm{m}$ ). Spiroplatanoxylon densiradiatum (Petrescu) Süss 2007, Bozovici, Romania.

a-c. (cross section) - distinct boundary of growth ring, diffuse-porous wood structure, ray dilatations at boundaries. d-f. Tangential section - two-sized rays - fine and multiseriate (d), spiral thickenings on vessels (f). g-i. Radial section - badly preserved scalariform perforation plates $(\mathbf{h})$, round simple pits in cross fields. 


\section{Macroscopic description}

A decimetric sized sample of petrified trunk (Fig. 3), displaying whitish color, fibrous texture and regular growth rings, was submitted to palaeoxylotomical study. From it, thin sections standard oriented were realized and a microscopic study was performed on them. The studied material originates in Bozovici depression, coming from midBadenian sediments (upper part of Valea Slătinicului Member of Lăpuşnicul Mare Formation), and is deposited in the National Geological Museum Collection (NGM Col., Bucharest) under the number 27,622.

\section{Microscopical description}

The growth rings are clearly distinct and the wood structure is diffuse-porous to semi-ring-porous. The multiseriate rays present typical dilatations at ring boundaries.

The vessels in cross section seen appear as solitary pores or as tangential pairs or diagonal or in clusters. Thay have angular section, slightly rounded or even deformed, and have moderately thick walls, of 7-10 $\mu \mathrm{m}$ the double wall. The woody fascicles, may have tangentially, between two rays, 1-6 vessels. In the early-wood the vessels are meansized, their diameters ratio $(\mathrm{r} / \mathrm{tg})$ is of $40-95 / 30-63 \mu \mathrm{m}$. Their relatively uniform size is gradually diminishing, in the late-wood, to (20)30-40/(15)20-30 $\mu \mathrm{m}$, so defining a diffuse-porous wood, tending to semi-ring-porous. The density of the vessels is $115-130$ per square mm. In radial section, scalariform perforations can be seen, on tilted plates, with 18-24 thin bars, quite poorly preserved. The walls of the vessels present bordered pits, opposite, horizontaly elongated, to scalariform by apertures' coalescence, and are rather badly preserved. Helical thickenings are also present, visible especially in tangential section. The length of vessels elements is difficult to measure. No tyloses were observed inside the vessels. Sometimes clusters of vascular tracheids appear, with similar pits, like on vessels.

The wood parenchyma apears in cross section of apotracheal type, diffuse, and appear scattered cells among the fibres, or as uniseriate short lines. In longitudinal view appear as strands of rectangular parenchyma cells, empty or with crystals inside, probably with simple pits on walls, quite poorly preserved. Vessels' elements length is difficult to measure.

The rays, in cross section appear two sized, show linear trajectory, and are formed by rectangular cells. The multiseriate rays have typical platanoid dilatations at growth ring boundaries. In tangential view they appear clearly twosized, of 1-4 and 8-12 cells wide, the multiseriate are fusiform and compact, have cell-sheath and are usually tall, having up to 30 cells in height, or more. The body ray cells are slightly polygonal, and unequally sized and relatively thick-walled, and the uniseriate ray-endings have 1-5 slightly polygonal cells. The ray-density is of 712 rays on tangential horizontal $\mathrm{mm}$. In radially view the rays are heterocellular, having procumbent body-cells and marginals square or taller. In cross-fields, poorly preserved glyptostroboid pits appear. Sometimes, secretory cells appear, often bearing crystals.
The fibres are angular in cross section, with rounded lumina and thick walls. Poorly preserved pits on the longitudinal walls were observed.

\section{Affinities and discussions}

After evaluating the microscopical features observed in our specimen regarding the diffuse-porous pattern of the pores in cross-section, typical dilated rays at growth-ring boundary ("platanoid dilatations"), typical pitting on vessels and on vascular tracheids and scalariform perforations and, also, the presence of helical thickenings, even poorly preserved, we found some generic similitudes with the platanaceous structure (Greguss, 1969).

There are three fossil genera created for platanaceous fossil woods: Plataninium, Platanoxylon and Spiroplatanoxylon.

The genus Plataninium has a long history: it was created in 1842 by Unger (published in Endlicher, 1842) as a "pocket taxon" for platanoid broad-rayed fossil wood, not illustrated but with a very comprising diagnosis based on the type-species $P$. acerinum Unger, described on a fossil wood coming from an unknown horizon and locality (see Crawley, 1989). It was emended by Vater (1884), unifying the diagnoses of Phegonium (or Fegonium) Unger, and Plataninium Unger. It was emended again by Felix (1894) and, later, by Page (1968), in order to comprise members of the families Fagaceae (Fagus type), Platanaceae (Platanus type), Eupteleaceae (Euptelea type) and Icacinaceae (Citronella, Ottoschultzia types), for specimens difficult to be assigned. After few times its diagnosis was emended again by Brett (1972) who admitted it as morphogenus, attributing to it four species: Plataninium decipiens Brett, 1972; P. europeanum Prakash, Březinova et Bůžek, 1971; P. haydenii Felix, 1896; $P$. brettii Crawley, 1989. Some years later, Süss and MüllerStoll (1977) consider Plataninium an inutile, ambiguous name that has to be invalidated.

Therefore, this name was several times subject of revision or dispute, some species being redescribed as belonging to other genera, for exemple: Plataninium subaffine Vater, 1884, that became Hedycaryoxylon subaffine (Vater) Süss, 1960; or Plataninium aceroides (Goeppert) Windisch, 1886, that became Fagoxylon acerinum (Windisch) Süss, 1986; or have been replaced by names as Platanus, Platanoxylon or Spiroplatanoxylon (see Edwards and Jogmans, 1931; Süss, 1960, 1971, 1986, 2007; Süss and Müller-Stoll, 1977).

The name Plataninium is still used by some American, Asian and even European scientists, and considered as a primitive type. This supports the Bayley concept regarding the evolution of the xylotomic features (see Süss, 1960) from Plataninium, which has scalariform perforations, spiral thickenings, marked heterocellular rays, to Platanoxylon, as an evolved type, which has simple perforations, no spiral thickenings and homocellular rays (Selmeier, 1996). Anyway, now Plataninium is usually described from sites with platanoid leaves from Cretaceous to Eocene of North America, Paleogene from Japan and even Upper Cenozoic in Europe (see Taylor \& Taylor, 1993). We cite here some species described in the last decades under the genus name Plataninium Unger (in Endlicher) emend. Vater, 1884: 
- P. obbruxellense Stockmans, 1936, described from the Eocene of Belgium. Specimens from Apuseni Mountains described as Platanoxylon cf. obbruxelense (Stockmans) Petrescu, 1969 and by Petrescu and Lazăr (1970) as having a slightly disordered structure, small pores, scalariform perforation plates and relatively thin rays.

- P. californicum Page, 1968 and P. platanoides Page, 1968 described from Cretaceous deposits of California.

- P. decipiens Brett, 1972, is also described by Crawley (1989), and by Poole et al. (2002) from similar Paleogene deposits (Eocene London Clay) of south-east England, and by Meijer (2000) from the Late Cretaceous of Belgium.

- P. brettii Crawley, 1989, is described on a badly preserved specimen, from Paleocene of Great Britain - Inner Hebrides.

- P. piercei Wheeler, McClammer et LaPasha, 1995, described from deposits of terminal Cretaceous to Paleocene of San Juan Basin, New Mexico, North America.

- P. jezoensis Takahashi et Suzuki, 2003 and P. ogasawarae Takahashi et Suzuki, 2003, described from Cretaceus of Japan.

The morphogenus Platanoxylon Andreánszky, 1951 (ex Prakash et al. 1971) was also subject of revision and dispute, at least in the last time (Süss \& Müller-Stoll, 1977; Süss, 2007, with references). After all these, a clear diagnosis has to separate the three admitted genera of fossil plants. Hence, after the revision of Süss (2007), some already described species were assigned to this morphogenus (Selmeier, 1996 considered it as organ-genus!) as it follows:

- Plataninium haydenii Felix, 1894, P. pacificum Platen, 1908 and $P$. crystallophilum Platen, 1908 were revised to Platanoxylon haydenii (Felix) Süss et Müller-Stoll, 1977, Platanoxylon pacificum (Platen) Süss et Müller-Stoll, 1977, and respectively to Platanoxylon crystallo-philum (Platen) Süss et Müller-Stoll, 1977.

- Moreover, six species were validated by Süss et MüllerStoll (1977) as correctly attributed to Platanoxylon: $P$. andreanszkyi Süss et Müller-Stoll, 1977, P. hungaricum Süss et Müller-Stoll, 1977, P. palibacsii Süss et MüllerStoll, 1977, P. sarmaticum Süss et Müller-Stoll, 1977, P. catenatum Süss et Müller-Stoll, 1977, also described by us in the South Apuseni Mountains (Iamandei \& Iamandei, 2000), and P. cohenii (Schuster) Süss, 1980, adding other generic identification as Platanoxylon sp., described from Hungary, Czech Republic and Germany by Andreánszky (1952), as belonging to Platanoxylon, according to Selmeier $(1996,2001)$ and Gottwald (2000). Also, the specimen described by Petrescu \& Vasiliu (1987) from Romania is a Platanoxylon.

After a special interest accorded to this type of fossil wood by Süss (2007, with references), a new taxon was created, „aus dem Tertiär von Europa und Vorderasie“, Spiroplatanoxylon Süss 2007, which is characterized, beside the plane-like wood structure, by two aspects considered more primitive, but characteristic to the genus: the scalariform perforation plates and the helical thickenings on vessels. The type-species was chosen Plataninium porosum Felix, 1887 - which was redescribed and transferred to Spiroplatanoxylon porosum (Felix) Süss, 2007 as comb. nova, and two new species of Spiroplatanoxylon were described:

12
- S. gregussii Süss, 2007, which has bigger vessels, mostly solitary and less frequent per square mm, very abundant tyloses, broad multiseriate rays and crystals in the axial parenchyma present as chambered cells or, rarely, as idioblasts.

- S. mueller-stollii Süss, 2007, quite similar, with mostly solitary vessels, less frequent per square mm, very abundant tyloses, generally thinner rays, which can even be aggregated and also broad multiseriate rays and crystals in the axial parenchyma present as chambered cells or, rarely, as idioblasts; the same species was identified by Továrková et al. (2011) from Brno area, Czech Rep.

Also, several species of Icacinoxylon, Platanoxylon and Plataninium are reidentified and placed into the genus Spiroplatanoxylon. It is very of note that even Page (1968) also emended once the genus Plataninium, to comprise broader-rayed structures, including members of the Icacinaceae (equivalents of Citronella, Ottoschultzia). - Plataninium europeanum Prakash, Březinová et Bůžek, 1971 found in northern Bohemia, was revised by Süss (2007) to Spiroplatanoxylon europeanum (Prakash, Březinová and Bůžek) Süss, having smaller vessels with scalariform perforated plates, spiral thickenings, crystals and low vessel frequency.

- Plataninium porosum Felix, 1887, found in Apuseni Mountains, at Almaşu Mare, was revised to Spiroplatanoxylon porosum (Felix) Süss, 2007, having spiral thickenings on vessels and long chains of crystalliferous parenchyma. The same species of Plataninium was described also by Petrescu and Nuţu (1970), from Boiu, South Apuseni Mountains, so it becomes Spiroplatanoxylon porosum (Felix) Süss, 2007 too.

- Platanoxylon bohemicum Prakash, Brezinova and Buzek, 1971 was revised to S. bohemicum (Prakash, Březinová and Bůžek) Süss, 2007, having high scalariform perforation plates, abundant tyloses and shorter rays. However, more recently, Sakala et al. (2010) revisiting the original site from where Prakash et al. (1971) have described Platanoxylon bohemicum, Plataninium europeanum and Dryoxylon bohemicum, have made microscopical observations on new slides and confirmed the presence of spiral thickenings and rare prismatic crystals in axial parenchyma cells in Plataninium but not in Platanoxylon. So, they decided to use the denomination Spiroplatanoxylon only for the Plataninium type of wood in which are observed spiral thickening and crystals. As a precaution, they kept the three morphospecies as separate units, even if they thought they all may represent the same botanical species. Also, it is of interest that Greguss (1967, 1969) have described some specimens as Icacinoxylon sp. seu Platanoxylon sp., or Icacinoxylon / Platanoxylon (see also Gryc \& Sakala, 2010). In fact, 18 badly preserved specimens studied by Greguss (1967), were identified as Icacinoxylon sp. seu Platanoxylon sp., having scalariform perforation plates, with 6-10, 18-20, or 30-35 bars, crystals inside vessels, parenchyma or rays, sometimes radial or axial canals, or typical platanoid aspect, and were, or must be attributed to Spiroplatanoxylon sp.:

- Andreánszky (1951) described Platanoxylon sp. with helical thickenings on vessels and scalariform perforations that could be Spiroplatanoxylon sp. (Süss, 2007). 
- S. citronelloides (Shilkina) Süss, 2007, was described by Shilkina (1956) as a species of Icacinoxylon, and then, was found again and described by Greguss (1967) as having vessels high scalariform perforation plates with numerous bars (30-50), spiral thickenings abundant tyloses and shorter rays.

- Spiroplatanoxylon hortobagyii (Greguss) Süss, 2007, (former Icacinoxylon) has oval vessels in cross-section, and shorter rays, beside the generic features.

- Spiroplatanoxylon shilkinae (Greguss) Süss, 2007, (former Icacinoxylon) has vessels with high scalariform perforation plates with numerous bars, and lower rays (to 8 cells broad), which can even be aggregated.

- Spiroplatanoxylon platanoides (Greguss) Süss, 2007, (former Icacinoxylon) has heterocellular rays with several rows of upright marginal cells. The species of Greguss was also described from the Apuseni Mountains by Petrescu (1978) even if on badly preserved specimens.

- Spiroplatanoxylon densiradiatum (Petrescu) Süss, 2007, (former Icacinoxylon) has smaller angular vessels, solitary or in clusters, 75 per square mm., and scalariform perforation plates with 20-35 bars, spiral thickenings, two-sized rays with high ray-frequency and ray-cells with crystals.

- Spiroplatanoxylon densiporosum (Petrescu) Süss, 2007, (former Icacinoxylon) has small and numerous vessels that show scalariform perforation plates with more numerous bars and spiral thickenings, long chains of crystalliferous parenchyma, high rays and terminal fibrous band.

- Spiroplatanoxylon romanicum (Petrescu) Süss, 2007, (former Icacinoxylon) have rather numerous vessels (5070 per square $\mathrm{mm}$ ) with high scalariform perforation plates with numerous bars (up to 30-35), spiral thickenings, secretory parenchyma cells, rays of 11-16 cells broad and very high.

Also, there are other described European species of Icacinoxylon that must be translated to Spiroplatanoxylon:

- Icacinoxylon crystallophorum Greguss, 1967 a species having high scalariform perforation plates, up to 55 bars and broad compact rays of 20 cells wide, found also by Petrescu (1978) and by Iamandei and Iamandei (1997) in the Apuseni Mountains, and must also be assigned to Spiroplatanoxylon cystallophorum (Greguss) Iamandei, comb. nova.

- Icacinoxylon sylvaticum (Tuzson) Greguss, 1969, and I. aff. sylvaticum (Tuzson) Greguss, 1969, described from Hungary and found again by Dupéron (1978) from the Stampien of Agenais, France, must become Spiroplatanoxylon sylvaticum (Tuzson) Iamandei, comb. nova, and respectively Spiroplatanoxylon aff. sylvaticum (Tuzson) Iamandei, comb. nova.

Discussing the attribution of a French wood to Icacinoxylon aff. sylvaticum (Tuzson) Greguss, 1969, Duperon (1976) wrote: "la seul espèce actuelle présentant des eléments de vaisseaux spiralés est Citronella mucronata, et la plupart des bois décrits sous le nom d'Icacinoxylon possèdent des éléments de vaisseaux spiralés. Faut-il en conclure d'emblée que l'évolution de la famille tend vers la disparition de cet ornement? Il serait bien hardi de l'affirmer. Cependant, Metcalfe and Chalk (1950) constatent que les bois à perforations de vaisseaux scalariformes ont plus fréquemment des spirales que les bois à perforations de vaisseaux simples et à structures étagées. Les perforations scalariformes étant un caractère d'autant plus primitif que le nombre de barres est élevé, on est tenté de penser que la plupart des bois fossiles d'Icacinaceae sont à caractères plutot archaïques".

- Another species of Icacinoxylon described from Georgia as I. goderdzicum Shilkina, 1958, has to be translated to Spiroplatanoxylon goderdzicum (Shilkina) Iamandei, comb. nova.

Some fossil woods described from the Romanian Carpathians and identified as Icacinoxylon both at species and genus level, must be discussed and correctly assigned to the valid accepted genus:

- Icacinoxylon tyleradiatum Iamandei et Iamandei, 1997, described from the latest Cretaceous deposits of Apuseni Mountains, having vessels with scalariform perforation plates with numerous bars, 20 or more, tyloses, spiral thickenings on vascular tracheids, or on small vessels, secretory parenchyma cells with dark content, two-sized rays, fine of 2-3 and broad of 12-16, dissected, high heterogeneous and heterocellular, 1-5 marginal square, or upright ray-cells, with gum and crystals inside, must become Spiroplatanoxylon tyleradiatum (Iamandei et Iamandei) Iamandei, comb. nova.

- Icacinoxylon grambastfessardi Petrescu, 1972 (in Petrescu \& Dragastan, 1972) from the Oligocene of Telega (Prahova county) must be redescribed as Spiroplatanoxylon grambastfessardi (Petrescu) Iamandei, comb. nova, even if no spiral thickenings were observed, but high scalariform perforation plates, with up to 25 bars, and twosized rays 1-4 seriate and fusiform, of up 16-20 cells broad, ray-cells with crystals.

- Numerous other specimens identified as Icacinoxylon sp., described from the late Miocene of Prăvăleni (Petrescu \& Nuţu, 1971, 1972), from the Oligocene from NW Transilvania (Petrescu, 1978) and from the Oligocene of Carpathians' Curvature (Petrescu et al., 1989) on specimens quite badly preserved, having semi-ring-porous wood, often diffuse, not too large solitary vessels or grouped in 2-3, with scalariform perforations, two-sized rays, fine of 1-4 cells wide and of 6-(10-12)-18 cells broad, either compact or aggregate, or dissected, heterogeneous with polygonal ray-cells, unequally sized and with crystals and few other details. They have obvious platanoid wood structure, and must be also assigned to Spiroplatanoxylon, as valid taxon.

Since the wood structure of the studied specimen from Bozovici resembles to many described specimens of Spiroplatanoxylon, especially to the forms described by Petrescu \& Dragastan, 1972) from the Oligocene of Telega and also by Petrescu and Nuţu (1972) from Prăvăleni, we tried to find very specific details to discriminate between them and we found a close identity with the species Spiroplatanoxylon densiradiatum (Petrescu) Süss, 2007, by having diffuse-porous to semi-ring porous distribution of the polygonal and not to large vessels (under $100 \mu \mathrm{m}$ in diameter), numerous two-sized rays, with platanoid dilation at ring boundary in cross-section, and scalariform perforations with 18-24-35 thin bars, with bordered pits, opposite, horizontally elongate to scalariform, with helical thickenings, with crystals in parenchyma, 
two-sized rays of 1-4 and 8-12 cells wide, high, fusiform, compact heterocellular, ray-cells with crystals, thickwalled fibres - angular in cross section. In these conditions, we assign our studied specimen to the species Spiroplatanoxylon densiradiatum (Petrescu) Süss, 2007.

\section{CONCLUSIONS}

In this paper, two fossil tree taxa have been described from the upper part of Badenian deposits from Bozovici, with different aspects and botanical affinities, as it folows:

- Glyptostroboxylon rudolphii Dolezych et Van der Burgh, 2004, probably was one of the main coalgenerator tree in the basin, similarly to other Miocene to Pliocene coaly basins of the neighbor regions (Oltenia), by its huge quantity of woody mass and maybe other plant-parts and by its probable habit, because it may had been a special extinct eco-form of Glyptostrobus, living in similar wet environment as the extant Taxodium lives (T,icleanu N., 2006, pers. comm.). Otherwise, the black aspect of the petrified wood suggests a stage of coalification before silicification. However, it is strange that the sporopollinic list given by Petrescu (2003) do not comprise pollen of Glyptostrobus also.

- Spiroplatanoxylon densiradiatum (Petrescu) Süss, 2007 could represent a platanaceous arboreal taxon (also absent from the sporopollinic list of Petrescu, 2003), living in the emerged neighbor riparian land, brought into the basin and buried during catastrophic rainfall and petrified by mineralizing solutions related with the tuff intercalations present in the volcano-sedimentary deposits.

New and systematic palaeoxylotomical research in Bozovici area could contribute to a better understanding of the sedimentation processes into the basin, of the botanical origin of the coals knowing the neighbor contemporaneous vegetation and of the palaeoenvironmental conditions, including the palaeoclimate reconstruction of that area during Badenian time.

\section{ACKNOWLEDGEMENTS}

The achievement of this paper was supported by the Geological Institute of Romania. Many thanks also we express to reviewers, Dr. Akkemik, Ü. and to Dr. Paraschiv V., who helped us improve the manuscript by their valuable suggestions. We also thank to Daniel Ţabără for redrawing the Fig. 1.

\section{REFERENCES}

Akkemik, Ü., Acarca, N. N. \& Hatipoğlu, M., 2017. The first Glyptostroboxylon from the Miocene of Turkey. - IAWA Journal, 38 (4): 561- 570.

Akkemik, Ü., Kiran Yildirim, D., Sakala, J., Akkiliç, H. \& Altinişik, A., 2019. New petrified wood descriptions from west-central Anatolia: contribution to the composition of the Neogene forest of Turkey. Neues Jahrbuch für Geologie und Paläontologie Abhandlungen, 292/1: 57-71.

Andreánszky, G., 1951. Der versteinerte Wald von Mikofálva und einge andere verkieselte Baumstämme aus Ungarn. Annales biologicae universitatum Hungariae, 1: 15-24.

Andreánsky, G., 1952. La répartition des fôrets de Platanes en Hongrie a l'époque tertiaire. Acta Biologica Academiae Hungaricae, 3: 151-158.

Barbu, I.E. \& Brănoiu, Gh., 2018. Depositional systems for the sedimentary deposits from the Lighidia perimeter, Bozovici, Caraș-Severin county. Romanian Journal of Mineral Deposits, 91 (1-2): 55-60.

Bartling, Fr.Th., 1830. Ordines naturales plantarum eorumque characteres et affinitates; adjecta generum enumeration. Göttingae, Dieterich: 541pp. .https://archive.org/details/ordinesnaturale00bartgoog

Brett, D.W., 1972. Fossil wood of Platanus from the British Eocene. Palaeontology, 15: 496-500.

Codarcea, Al., Răileanu, Gr., Năstăseanu, S., Bercia, I., Bercia, E. \& Bițoianu, C., 1968. Geological maps of Romania, Scale 1:200,000, Sheet 31 - Reşiţa and Sheet 32 - Baia de Aramă. Edited by the Geological Institute of Romania, State Comitee of Geology.

Codrea, A.V., 2002. Badenian Insectivores from Bozovici Basin (Southern Carpathians, Caraş-Severin District). Acta Paleontologica Romaniae, 3(2001): 67-75.

Conwentz, H., 1884. Sobre algunos árboles des Rio Negro. Bolletin Acad. Nacional Ciencias, Córdoba, 7:435-456.

Crawley, M., 1989. Dicotyledonous wood from the lower Tertiary of Britain. Palaeontology, 32(2): 597 - 622.

Dolezych, M. \& Van der Burgh, J., 2004: Xylotomische Untersuchungen an inkohlten Hölzern aus dem Braunkohlentagebau Berzdorf (Oberlausitz, Deutschland). Feddes Repertorium, 115: 397-437.

Dupéron, J., 1978. Présence is d'Icacinaceae dans le Stampien de l'Agenais. Compte Rendus du 103e Congres National des Sociétés Savantes, Nancy, Fasc. II: $177-185$.

Earle, C.J., 1998. Gymnosperm Database. Internet Online: http://www.conifers.org/index.php.

Edwards, W.N. \& Jogmans, W. (eds.), 1931. Fossilium Catalogus. II. Plantae: Pars 17. Dicotyledones (Ligna), 95 pp. W. Junk, Berlin W 15. url: https://books.google.ro/books?id=C0xOC0jK7qMC\& $\mathrm{pg}=$ PA61\&lpg=PA61\&dq=Vater $+(1884) \&$ source

Erdei, B., Dolezych, M. \& Hably, L., 2009: The buried Miocene forest at Bükkábrány, Hungary. Review of Palaeobotany and Palynology, 155(1-20): 69-79, url: http://dx.doi.org/10.1016/j.revpalbo.2009.01.003

Endlicher, S., 1842. Taxineae, Mantissa Botanica Sistems. Generum Plantarum, Supplementum Secundum, F. Beck, Vienna: 27-28.

Fairon-Demaret, M., Steurbaut, E., Damblon, F., Dupuis, C., Smith, T. \& Gerienne, P., 2003. The in situ Glyptostroboxylon forest of Hoegaarden (Belgium) at the Initial Eocene Thermal Maximum (55 Ma). Review of Palaeobotany and Palynology, 126: 103-129.

Farjon, A., 2005. A monograph of Cupressaceae and Sciadopitys.- 648 pp.; Kew (Royal Botanic Gardens, Kew).

Farjon, A., 2017. A Handbook of the World's Conifers (2 vols.), Vol. I. Revised and Updated Edition. Brill Leiden-Boston: $1153 \mathrm{p}$

Felix, J., 1887. Beitrage zur Kenntniss der fossilen Holzer Ungarns. Mittheilungen aus dem Jahrbuche der Ko- 
nig. Ungarischen Geologischen Anstalt, VIII : 145162.

Felix, J., 1894. Untersuchungen uber fossile Hölzer, IV. (Hölzer aus dem Kaukasus). Zeitschrift der Deutschen Geologischen Gesellschaft, XLVI: 79-110.

Felix, J., 1896. Untersuchungen uber fossile Hölzer,V. Zeitschrift der Deutschen Geologischen Gesellschaft, XLVIII: 249-260.

Gadek, P., Alpers, D., Heslewood, M.M. \& Quinn, C.J., 2000. Relationships within Cupressaceae sensu lato: a combined morphological and molecular approach. America Journal of Botany, 87(7): 1044-1057.

Gray, S.F., 1822. A Natural Arrangement of British Plants (Nat. Arr. Brit. Pl.), 2: 222, 225.

Gothan,W., 1905. Zur Anatomie lebender und fossiler Gymnospermen Hölzer. Abhandlungen der Königlich Preussischen Geologischen Landesanstalt, Neue Folge, 44: 1-108.

Gottwald, H., 2000. Gymnosperme und dicotyle Hölzer (67) aus den "Aachener Sanden" der Oberen Kreide von NO-Belgien und NW-Deutschland. Documenta Naturae, 131: 1-65.

Greguss P., 1955. Identification of living Gymnosperms on the basis of xylotomy. Akademiai Kiado, pp. 263+350pl.

Greguss P., 1967. Fossil Gymnosperm woods in Hungary, from the Permian to the Pliocene. Akademiai Kiado, pp. 1-152+93 pl.

Greguss, P., 1969. Tertiary Angiosperm woods in Hungary. Akádemiai Kiádo, Budapest, pp.1-152+93pl.

Grigorescu, D., 1985. Asupra prezenței lui Brachiodus onoideus (Gervais) în depozitele neogene din Bazinul Bozovici, și semnificaţia lui biostratigrafică. Studii și cercetări de geologie, geofizică, geografie. Geologie, 30: 122-128, [in Romanian].

Gryc, V.J. \& Sakala, J., 2010. Identification of fossil trunks from Bükkábrány newly installed in the Visitor Centre of the Ipolytarnóc Fossils Nature Reserve (Novohrad - Nógrád Geopark) in Northern Hungary. Acta Universitatis Agriculturae et Silviculturae Mendelianae Brunensis, LVIII(5): 117-122.

Havelcová, M., Sýkorová, I., Bechtel, A., Mach, K., Trejtnarová, H., Žaloudková, M., Matysová, P., Blažek, J., Boudová, J. \& Sakala, J., 2013. "Stump Horizon" in the Bílina Mine (Most Basin, Czech Republic) -GC-MS, optical and electron microscopy in identification of wood biological origin. International Journal of Coal Geology, 107: 62-77.

Hofmann, E., 1952. Pflanzenreste aus dem Phosphoritvorkommen von Prambachkirchen Im Oberöstereich, II Teil. Palaeontographica Abt. B, 92(3-6): 122-138.

Iamandei, E. \& Iamandei, S., 1997. Xylotomical study of some fossil dicot trunks from Techereu, Metalliferi Mountains Acta Palaeontologica Romaniae, 1: 107112.

Iamandei, E. \& Iamandei, S., 2000. Platanoxylon catenatum Süss et Müller-Stoll in Bacea area, Metalliferous Mountains. Révue Roumaine de Géologie, Acad. Roum., 43(1999): 65-67.

Iamandei S. \& Iamandei E., 2000. Fossil Conifer Wood from Prăvăleni-Ociu, Metalliferous Mountains. Acta Palaeontologica Romaniae, II(1999): 201-212.
Iamandei, S., Iamandei, E. \& Ţibuleac, P., 2001. Fossil Wood from Coal-layer "B" of Volhinian Formation in Leucuşeşti - Fălticeni area. Analele Ştiinţifice ale Universităţii "Al.I.Cuza" (sr.n.), Geologie, 47: 211218.

ICBN, 2011. International Code of Nomenclature for algae, fungi, and plants (Melbourne Code). Regnum Vegetabile, 154. Koeltz Scientific Books. http://www.iapt-taxon.org/nomen/main.php

Iliescu, O., Radu, A., \& Lica, M., 1967. Geologia Bazinului Bozovici. Dări de Seamă ale Institutului Geologic, LIII (1): 341-366, [in Romanian].

InsideWood, 2004 - onwards. Published on the Internet: (http://insidewood.lib.ncsu.edu/search) [accessed 01.10.2016].

Jurasky K.A., 1933. Glyptostroboxylon tenerum (Kraus) Conwentz in der oberpliozaenen Braunkohle von Woelfersheim (Wetterau). Braunkohle, 40: 746-750.

Kostyniuk, M., 1938. Trzeciorzędowe drewna i pyłki z Mazowsza i Wołynia (summary: Ueber die tertiären Pollen und Koniferenhölzer von einigen Gegenden Polens). Kosmos (Lwow), 63: 1-33.

Koutecky, V. \& Sakala, J., 2015. New fossil woods from the Paleogene of Doupovske hory and Česke středohoři Mountains (Bohemian Massif, Czech Republic). Acta Musei Nationalis Pragae, Series B Historia Naturalis, 71(3-4): 377-398.

Kraus, G., 1864. Mikroskopische Untersuchung über den Bau lebender und vorweltlicher Nadelhölzer. Würzburg Naturwissenschaft Zeitschrift 5: 144-200.

Kräusel, R., 1949. Die fossilen koniferen-Holzer (unter ausschluss von Araucarioxylon Krauss). II Teil. Kritische Untersuchungen zür diagnostic Lebender und Fossilen Koniferen-Hölzer. Palaeontographica Abt. B, 89(4-6): 83-203.

Kvaček, Z., 1998. Bílina: a window on Early Miocene marshland environments. Review of Palaeobotany and Palynology, 101: 111-123.

Kvaček, Z. \& Bůžek, Č., 1982. Třetihorní rostlinná spole čenstva severočeské hnédouhelné pánve ve vztahu k litofaciálnímu vývoji. - 46 pp. Praha (Ústřední ústav geologický).

Meijer, J.I.F., 2000. Fossil woods from the Late Cretaceous Aachen Formation. Review of Palaeobotany and Palynology, 112: 297-336.

Metcalfe, C.R. \& Chalk., L., 1950. Anatomy of the dicotyledons. Vol. 1 and 2. Clarendon Press, Oxford.

Nagy, F., Petrescu, I. \& Mârza, I., 2002. La présence d'un bois de Glyptostroboxylon dans le Miocène de Prăvăleni - Brad. Contribuţii Botanice, Grădina Botanică "Alexandru Borza" Cluj-Napoca, XXXVII: 293-298.

Oprea, C.R., 2014. Carpaţii Româneşti - Date geologice. Caracteristici generale. Curs 1 online, 24p. [in Romanian]. url:http://www.unibuc.ro/prof/oprea_c_r/docs/2014/n oi/25_00_15_20Carpati_geologie.pdf

Page, V.M., 1968. Angiosperm wood from the Upper Cretaceous of Central California: Part II. American Journal of Botany, 55: 168-172.

Petrescu, I., 1969. Flora oligocenă din bazinul văii Almaşului (NV României). Teza de Doctorat, Universitatea din Bucureşti [in Romanian, unpublished]. 
Petrescu, J., 1978: Studiul lemnelor fosile din Oligocenul din Nord-vestul Transsilvaniei. Mémoires de l'Institut de Géologie et de Géophysique, 27: 115-184. [in Romanian].

Petrescu, I., 2003. Palinologia Terţiarului. Edit. Carpatica, Cluj-Napoca (249 p.): 161-163, [in Romanian].

Petrescu, I. \& Dragastan, O., 1972. Asupra unor lemne de Icacinoxylon Shilkina din Oligocenul de la TelegaPrahova. Studii și cercetări de geologie, geofizică, geografie. Geologie, 17(2): 445 -451 [in Romanian].

Petrescu, I. \& Lazăr, I., 1970. Date anantomice ale unor trunchiuri din Oligocenul de la Fildu de Jos (NV Romaniei). Sargetia (Acta Musei Devensis), sr. Sc. Nat., VII: 259-266. [in Romanian].

Petrescu, I. \& Nuţu, A., 1970. Alte tipuri de lemne din miocenul superior de la Prăvăleni - Brad. Sargetia (Acta Musei Devensis), sr. Sc. Nat., VII: 253-258. [in Romanian].

Petrescu, I. \& Nuţu, A., 1971. Asupra unor noi aflorimente de lemne fosile din Miocenul superior al muntilor Metaliferi. Sargetia (Acta Musei Devensis), sr. Sc. Nat., VIII: 9-15. [in Romanian].

Petrescu, I. \& Nuţu, A., 1972. Asupra unui lemn de Icacinoxylon Shilkina în Miocenul superior de la Prăvăleni - Brad. Sargetia (Acta Musei Devensis), sr. Sc. Nat., IX: 77-79. [in Romanian].

Petrescu, I. \& Nicorici, E., 1989. Palynological studies of the, Lower Miocene deposits in the Bozovici Basin. Studia Universitatis Babeș-Bolyai, GeologiaGeographia, 34 (2): 43-45.

Petrescu, I. \& Vasiliu, M., 1987. On a Platanus wood (Platanoxylon) from the upper Miocene in the Metalliferous Mountains (Romania). Contribuţii Botanice, Cluj Napoca, 24: 83-89.

Platen, P., 1908. Untersuchungen fossiler Hölzer aus dem Westen der Vereinigten Staaten von Nordamerika. Verlag von Quelle and Meyer, Leipzig, 34/1907: 65111. (http://biodiversitylibrary.org/page/47203020)

Pomârleanu, V. \& Mârza, I., 2002. Implications resulting from the study of fluid inclusions in the shear zonetype gold mineralization from Bozovici (Banat) and Someșul Rece (Gilău mountains). Studia Universitatis Babeş-Bolyai, Geologia, 47: 105-106.

Poole, I., Davies, K.L. \& Wilkinson, H.P., 2002. A review of the platanaceous woods from the Eocene paratropical rainforest of south-east England. Botanical Journal of the Linnean Society, 139: 181-191.

Prakash, U., Březinova, D. and Bůžek, Č. 1971. Fossil woods from the Doupovske hory and Česke středohoři Mountains in Northern Bohemia. Palaeontographica, Abteilung B, Paläophytol. 133: 103-128.

Privé-Gill, C., 1977. Taxodioxylon gypsaceum (Goeppert) Kräusel, bois fossile du Tertiaire de Limagne (France). C. R. du 102e Congrés National des Sociétés Savantes, Limoges, 1977, sciences, fasc. I: 187196.

Ramanujam, C.G.K., 1960. Silicified woods from Tertiary rocks of South India. Palaeontographica Abt. B., 106(4-6): 99-140.

Rudolph, K., 1935. Mikrofloristiche UntersuchungenTertiärer Ablagerungen im Nordlistchen Bohmen. Beihefte zum Botanische Zentralblatt, 54, 244-328.
Sakala, J., Rapprich, V. \& Pécskay, Z., 2010. Fossil angiosperm wood and its host deposits from the periphery of a dominantly effusive ancient volcano (Doupovské hory Volcanic Complex, Oligocene-Lower Miocene, Czech Republic): systematics, volcanology, geochronology and taphonomy. Bulletin of Geosciences, 85(4): $617-$ 629.(http://www.geology.cz/bulletin/fulltext/1196_sa kala.pdf)

Selmeier, A., 1996. Tertiary Platanus woods from the northalpine Molasse basin (Austria, Germany). Mitteilungen der Bayerischen Staatssammlung für Paläontologie und Historische Geologie, 36: 157-183.

Selmeier, A., 2001. Silicified Miocene woods from the North Bohemian Basin (Czech Republic) and from Kuzuluk, district Adapazari. Mitteilungen der Bayerischen Staatssammlung für Paläontologie und Historische Geologie, 41: 111-144.

Seward, A.C., 1919. Fossil Plants vol IV Ginkgoales, Coniferales, Gnetales. Cambridge University Press. https://books.google.ro/books?id=bJY4AAAAIAAJ\& pg=PA198

Shilkina, I.A., 1956. Rod Icacinoxylon Shilkina gen. nov. (in Kipariaova et al.) Geologiceskii Institut (VSEGEI), Paleontologia, N. S., 12. [in Russian].

Shilkina, I.A., 1958. The fossil woods of the Goderdzy Pass. Paleobotanika, III: 127-179 [in Russian].

Stockmans, F., 1936. Végétaux éocènes des environs de Bruxelles. Mémoires du Musée royal d'histoire naturelle de Belgique, 76: 3-56.

Süss, H. 1960. Ein Monimiaceen-Holz aus der oberen Kreide Deutschlands, Hedycaryoxylon subaffine (Vater) nov. comb. Senckenbergiana lethaea, 41: 317330.

Süss, H., 1971. Über das Vorkommen von Platanen und platanenähnlichen Holzresten im Miozän der Ungarischen V. P. Geologie, 20: 74-81.

Süss, H., 1980. Ein Platanenholz aus dem Untereozän der Greifswalder Oie Platanoxylon cohenii (Schuster) comb. nov. Schriftenreihe Geologischen Wißenschaften Berlin 16: 401-416.

Süss, H., 1986. Untersuchungen über fossile Buchenhölzer. Beiträge zu einer Monographie der Gattung Fagoxylon Stopes and Fujii. Feddes Repertorium, 97: 61-183.

Süss, H., 2007. Holzfossilien der Morphogattung Spiroplatanoxylon gen. nov. aus dem Tertiar von Europa und Vorderasien. Feddes Repertorium, 118:1-19.

Süss, H. \& Müller-Stoll, W.R., 1977. Untersuchungen uber fossile Platanenhölzer. Beiträge zu einer monographie der Gattung Platanoxylon Andreánszky. Feddes Repertorium, 88:1-62.

Süss, H. \& Velitzelos, E., 1997. Fossile Hölzer der Familie Taxodiaceae aus tertiären Schichten des Versteinerten Waldes von Lesbos, Griechenland. Feddes Repertorium, 108(1-2): 1-30.

Takahashi, K. \& Suzuki, M. 2003. Dicotyledonous fossil wood flora and early evolution of wood characters in the Cretaceous of Hokkaido, Japan. IAWA Journal, 24: 269-309.

Taylor, T. N. \& E. L. Taylor. 1993. The Biology and Evolution of Fossil Plants. Prentice-Hall, Inc., Englewood Cliffs, New Jersey, USA. 
Teodoridis, V. \& Sakala, J., 2008. Early Miocene conifer macrofossils from the Most Basin (Czech Republic). Neues Jahrbuch für Geologie und Paläontologie Abhandlungen, 250: 287-312.

Torrey, R.E., 1923. The Comparative Anatomy and Phylogeny of the Coniferales. Part 3. Mesozoic and Tertiary Coniferous Woods. Memoirs of the Boston Society of Natural History, 6: 39-106.

Továrková, I., Gryc, V. \& Sakala, J., 2011. First anatomically characterized wood from the Tertiary of Moravia: Spiroplatanoxylon from the area of Austerlitz (Southern Moravia, Czech Republic). Acta Universitatis Agriculturae et Silviculturae Mendelianae Brunensis, 2011, LIX(6): 367-372.

Vassio, E., Martinetto, E., Dolezych, M. \& Van der Burgh, J., 2008. Wood anatomy of the Glyptostrobus europaeus "whole-plant" from a Pliocene fossil forest of Italy. Review of Palaeobotany and Palynology 151: 81-89.

Vater, H., 1884. Die Fossilen Hölzer der Phosphoritlager thums Braunscweig. Zeitschrift der Deutschen Geologischen Gesellschaft: 783-853.
Visscher, G.E. \& Jagels, R. 2003. Separation of Metasequoia and Glyptostrobus (Cupressaceae) based on wood anatomy. IAWA Journal, 24:439-450.

Watari, S., 1948. On a new species of Glyptostroboxylon. Shokubutsugaku Zasshi (The Botanical Society of Japan), 61(715-716): 11-14. https:// www.jstage.jst. go.jp/article/jplantres1887/61/715-716/61_715716_11/_article

Wheeler, E.A., McClammer, J., \& LaPasha, C.A., 1995. Similarities and differences in dicotyledonous woods of the Cretaceous and Paleocene, San Juan Basin, New Mexico, USA. IAWA Journal, 16(3): 223-254.

Windisch, P., 1886. Beitrage zur Kenntniss der Tertiärflora von Island. Zeitschrift für Naturwissenschaften, LIX: 215-262.

Zalewska, Z., 1953. Trzeciorzędowe szczątki drewna z Turowa nad Nysą Łużycką. Część I. Acta Geologica Polonica, III(4): 481-543. 